\title{
SCALAR MULTI-POINT BOUNDARY VALUE PROBLEMS AT RESONANCE
}

\section{DANIEL MARONCELLI}

Abstract. In this paper we discuss the solvability of multi-point boundary value problems of the form

$$
y^{(n)}(t)+a_{n-1}(t) y^{(n-1)}(t)+\cdots+a_{0}(t) y(t)=g(t, y(t))
$$

subject to

$$
\sum_{j=1}^{n} b_{i j}(0) y^{(j-1)}\left(t_{0}\right)+\sum_{j=1}^{n} b_{i j}(1) y^{(j-1)}\left(t_{1}\right)+\cdots+\sum_{j=1}^{n} b_{i j}(k) y^{(j-1)}\left(t_{k}\right)=0
$$

for $i=1, \cdots, n$.

We improve upon existing results in the literature regarding multi-point boundary value problems. Our approach uses an alternative method along with Schaefer's fixed point theorem.

Mathematics subject classification (2010): 34B10.

Keywords and phrases: multi-point boundary value problems, resonance, Lyapunov-Schmidt procedure, Schaefer's Fixed Point Theorem.

\section{REFERENCES}

[1] Z. DUA, X. LIN, AND W. GE, Some higher-order multi-point boundary value problems at resonance, J. Comput. Appl. Math., 177 (2005), 55-65.

[2] M. FENG AND W. GE, Existence results for a class of nth order m-point boundary value problems in banach spaces, Appl. Math. Lett., 22 (2009), 1303-1308.

[3] M. HiLAL, Multi-point boundary value problems, Lambert Academic Publsihing, 2012.

[4] J. Henderson AND R. LuCA, Positive solutions for system of nonlinear second-order multipoint boundary value problems, Math. Meth. Appl. Sci., 37 (2014), 2502-2516.

[5] W. JiAng, B. WANG, AND Z. WANG, Solvability of a second-order multi-point boundary-value problems at resonance on a half-line with $\operatorname{dim} \mathrm{ker} l=2$. Electron. J. Differential Equations, 2001, (2011), 1-11.

[6] Chan-Gyun Kim, Solvability of multi-point boundary value problems on the half-line. J. Nonlinear Sci. Appl., 5 (2012), 27-33.

[7] S. LIANG AND J. ZHANG, The method for lower and upper solution to 2nth-order multi-point boundary value problems, Nonlinear Anal., 71, (2009), 4581-4587.

[8] Xinan Hao Lishan LiU and Yongohong Wu, Multi-point boundary value problems for higher oder differential equations, Appl. Math. E-Notes, 4 (2004), 106-113.

[9] X LiU AND W LI, Positive solutions for the nonlinear fourth-order beam equations with three parameters, J. Math. Anal. Appl., 303 (2005), 150-163.

[10] R. MA, Multiple positive solutions for nonlinear m-point boundary value problems, Appl. Math. Comput., 148 (2004), 249-262.

[11] D. Maroncelli AND J. RodRíGUEZ. On the solvability of multipoint boundary value problems for discrete systems at resonance, J. Difference Equ. Appl., 20, Issue 1 (2013), 24-35.

[12] D. MARONCELli AND J. RodRíGUEZ, A least squares solution to linear boundary value problems with impulses, Differ. Equ. Appl., 5, Issue 4 (2013), 519-525. 
[13] D. Maroncelli And J. RodríGUeZ, Weakly nonlinear boundary value problems with impulses, Dyn. Contin. Discrete Impuls. Syst. Ser. A Math. Anal., 20 (2013), 641-656.

[14] D. MARONCELli AND J. RodRÍGUEZ, Existence theory for nonlinear sturm-liouville problems with unbounded nonlinearities. Differ. Equ. Appl., 6 (2014), 455-466.

[15] D. Maroncelli AND J. RodríGUez, On the solvability of nonlinear impulsive boundary value problems, Topol. Methods Nonlinear Anal., 44 (2015), 381-398.

[16] M. Moshins Ky, Sobre los problemas de condiciones a la frontiera en una dimension de caracteristicas discontinuas, Bol. Soc. Mat. Mexicana, 7 (1950), 1-25.

[17] Jesús ROdRÍGUEZ AND PADRAIC TAYLOR, Multipoint boundary value problems for nonlinear ordinary differential equations, Nonlinear Anal., 68 (2008), 3465-3474.

[18] S. Timoshenko, Theory of elastic stability, McGraw-Hill, New York, 1961.

[19] Y. M. WANG, The iterative solutions to 2nth-order nonlinear multi-point boundary value problems, Appl. Math. Comput., 217 (2010), 2251-2259.

[20] J.S.W. Wong AND L. Kong, Positive solutions for higher order multi-point boundary value problems with nonhomogeneous boundary conditions, J. Math. Anal. App., 367 (2010), 367-588.

[21] Wei-hua Jiang XiU-Jun LiU And YAn PING Guo, Multi-point boundary value problems for higher oder differential equations, Appl. Math. E-Notes, 4 (2004), 106-113. 